\title{
PENGARUH PEMANIS TERHADAP MUTU FISIK, KIMIA, DAN SENSORIS ES KRIM SARI KEDELAI JERUK MANIS (Citrus sinensis)
}

\author{
EFFECTS OF SWEETENERS ON PHYSICAL, CHEMICAL, AND SENSORY QUALITY OF \\ SOYMILK ICE CREAM WITH ORANGE JUICE (Citrus sinensis) ADDITION
}

\author{
Rauda Alfadila, R. Baskara Katri Anandito, dan Siswanti \\ Program Studi Ilmu Teknologi Pangan Fakultas Pertanian, Universitas Sebelas Maret, Surakarta \\ E-mail: raudaalfa@student.uns.ac.id
}

Diserahkan [25 Februari 2020]; Diterima [4 Juni 2020]; Dipublikasi [22 Juni 2020]

\begin{abstract}
Ice Cream is a type of frozen food as a result from the process of stirring and freezing a mixture of milk and other ingredients. Soy milk which is rich in protein can be an alternative subtitution for dairy milk in ice cream. Soy milk ice cream taste can be improved by adding sweeteners and fruit juice. Sweeteners are known to affect viscosity, texture, taste, and overrun of ice cream. The purpose of this study is to determine the effects of sweeteners on physical, chemical and sensory properties of soy milk ice cream with the addition of sweet orange juice. The experimental design used in the study was a Completely Randomized Design (CRD) with 1 treatment factor. In this study, 4 formulations of ice cream samples were produced using $12.5 \%$ sucrose, $8.3 \%$ sucrose $+4.16 \%$ fructose mixtures, $8.3 \%$ sucrose $+4.16 \%$ glucose mixtures, and stevia 1\%. The physical, chemical and sensory properties analyzed were overrun, resistance, total dissolved solids, protein content, fat content, total calories, antioxidant activity, vitamin $C$ content, and organoleptics. The results showed that the type of sweeteners used affected the physical and chemical properties of ice cream, but did not significantly affect the sensory properties. The best formulation is F1, orange soy milk ice cream with $8.3 \%$ sucrose $+4.16 \%$ fructose mixtures. F1 showed the highest overrun $(41.15 \%)$ with the lower melting resistance for $664.33 \mathrm{~s}$, and $46^{\circ}$ Brix of total dissolved solids. F1 resulted in high protein content $(5.21 \%)$, quite low fat content $(0.034 \%)$, high antioxidant activity $(63.88 \%)$, vitamin C content $(0.241 \%)$, and total calorie of $1929.37 \mathrm{kal} / \mathrm{g}$. F1 had the best sensory acceptance among all treatments.
\end{abstract}

Keywords: ice cream, orange juice, soy milk, sweetener

\begin{abstract}
ABSTRAK
Es Krim merupakan salah satu jenis makanan beku sebagai hasil dari proses pengadukan dan pembekuan campuran susu dan bahan lainnya. Sari kedelai yang kaya akan protein dapat menjadi alternatif pengganti susu sapi pada es krim. Cita rasa es krim sari kedelai dapat diperbaiki dengan penambahan pemanis dan sari buah. Pemanis diketahui dapat mempengaruhi viskositas, tekstur, rasa, dan overrun es krim. Tujuan dari penelitian ini adalah untuk mengetahui pengaruh jenis pemanis terhadap sifat fisik, kimia, dan sensoris es krim sari kedelai jeruk manis. Rancangan percobaan dalam penelitian menggunakan Rancangan Acak Lengkap (RAL) dengan 1 faktor perlakuan. Variasi pemanis yang digunakan adalah sukrosa $12,5 \%$, kombinasi sukrosa $8,3 \%$ fruktosa $4,16 \%$, kombinasi sukrosa $8,3 \%$ glukosa $4,16 \%$, dan stevia $1 \%$. Sifat fisik, kimia, dan sensoris yang dianalisis yaitu overrun, resistensi, total padatan terlarut, kadar protein, kadar lemak, total kalori, aktivitas antioksidan, kadar vitamin C, dan organoleptik. Hasil penelitian menunjukkan bahwa jenis pemanis yang digunakan mempengaruhi sifat fisik dan kimia es krim, namun tidak berpengaruh nyata terhadap sifat sensorinya. Formulasi terbaik adalah F1 yakni es krim sari kedelai jeruk manis dengan pemanis kombinasi sukrosa 8,3\% fruktosa 4,16\%. Formulasi es krim F1 menghasilkan overrun $41,15 \%$, resistensi pelelehan selama 664,33 detik, total padatan $46^{\circ}$ Brix, kadar protein $5,21 \%$, kadar lemak 0,034\%, total kalori sebesar 1929,37 kal/g, aktivitas antioksidan $63,87 \%$, serta kadar vitamin C $0,241 \%$. Hasil uji organoleptik F1 secara keseluruhan memperoleh skor kesukaan tertinggi.
\end{abstract}

Kata kunci: es krim, pemanis, sari jeruk manis, sari kedelai

\section{PENDAHULUAN}

Es krim adalah salah satu jenis makanan beku yang saat ini digemari oleh berbagai kalangan masyarakat. Proses pembuatan es krim terdiri dari pembekuan campuran susu, penstabil, gula, pengemulsi, dan bahan lainnya yang telah dipasteurisasi dan dihomogenisasi agar hasil adonannya seragam (Darma dkk., 2013). Prinsip 
pembuatan es krim yakni pembentukan rongga udara antar campuran bahan es krim menyebabkan terjadinya pengembangan volume, sehingga tekstur es krim menjadi lembut, tidak terlalu padat, dan lebih ringan (Failisnur, 2013). Es krim pada umumnya dibuat dari susu sapi, namun tidak semua orang dapat mengkonsumsi es krim berbahan dasar susu sapi. Bagi penderita lactose intolerance, laktosa pada susu tidak dapat dicerna, sehingga dapat menimbulkan gejala sakit perut hingga diare (Sumarijana, 2011). Produk es krim berbahan nabati dapat menjadi alternatif bagi para penderita lactose intolerance. Sari kedelai dapat dijadikan alternatif bahan pengganti susu dalam es krim (Darma dkk., 2013).

Kedelai (Glycine $\max ($ L.) Merr) merupakan salah satu dari sekian jenis legum yang memiliki gizi tinggi (Terhaag et al., 2013). Kandungan protein kedelai sekitar $40 \%$, kandungan tersebut tertinggi dibandingkan kacang-kacangan lain (Sumarno dan Harnoto, 1983). Selain kaya akan protein, sari kedelai juga merupakan sumber karbohidrat, lipid, vitamin, dan mineral (Hajirostamloo, 2009). Sari kedelai memiliki komposisi asam amino dan kadar protein yang hampir sama dengan susu sapi serta tidak mengandung laktosa (Violisa dkk., 2012). Namun olahan kedelai memiliki beberapa hal yang kurang disukai oleh konsumen yakni bau langu, rasa pahit, dan rasa seperti kapur. Bahan alami seperti sari buah dapat ditambahkan untuk meningkatkan cita rasa sari kedelai (Wahyuni, 2016).

Buah jeruk manis (Citrus sinensis) merupakan buah yang mengandung karbohidrat sederhana dan karbohidrat kompleks. Karbohidrat sederhana pada buah jeruk yaitu fruktosa, glukosa dan sukrosa (Andani dan Nurmasari, 2017). Sari buah jeruk mengandung 40 - $70 \mathrm{mg}$ vitamin $\mathrm{C}$ per $100 \mathrm{~g}$ bahan. Jeruk juga mengandung kalium, vitamin B kompleks, dan hesperidin (Sari dan Amelia, 2018). Komponen gula pada sarinya sebesar 4,93 - 7,57 g, yang terdiri dari glukosa 1,02 - 1,24 g; fruktosa 1,49$1,58 \mathrm{~g}$; sukrosa $2,19-4,90 \mathrm{~g}$ serta asam malat $0,18-0,21 \mathrm{~g}$ dan asam sitrat $0,80-1,22$ $\mathrm{g}$ per $100 \mathrm{ml}$ sari buah jeruk (Wariyah, 2010).
Penelitian tentang es krim berbahan dasar sari kedelai sebelumnya telah dilakukan oleh Putri (2014) yang memberikan penambahan ekstrak rosella pada es krimnya untuk menutupi bau langu dan rasa kedelai yang kuat agar dapat diterima oleh panelis. Berdasarkan penelitian tersebut, es krim sari kedelai pada penelitian ini dilakukan penambahan sari jeruk. Ketersediaan jeruk manis yang melimpah, ekonomis, mudah diperoleh, serta kandungan vitamin $\mathrm{C}$ yang tinggi menjadi alasan pemilihan buah jeruk manis sebagai bahan tambahan es krim yang dapat meningkatkan rasa es krim sari kedelai.

Selain penambahan sari buah sebagai penunjang rasa, bahan yang juga sangat berpengaruh terhadap cita rasa es krim adalah pemanis. Derajat kemanisan es krim ditentukan oleh pemanis yang digunakan. Jenis pemanis dapat mempengaruhi tekstur karena berkaitan dengan viskositas adonan. Pemanis dengan berat molekul yang tinggi, akan menghasilkan viskositas yang lebih tinggi (Clarke, 2004). Es krim yang memiliki flavor berbeda juga memiliki overrun yang bervariasi, tergantung dari kerapatan dan rasio bahan khusus yang ditambahkan (Goff dan Hartel, 2004). Pemanis memiliki efek dalam menurunkan titik beku, mengontrol jumlah air beku dalam es krim serta kelembutan dari produk akhir (Andreasen dan Nielsen, 1998). Rasio penambahan beberapa jenis pemanis dalam penelitian ini merujuk pada pada penelitian Junior dan Lannes (2011) yakni sukrosa, sukrosafruktosa, sukrosa-glukosa dengan presentase minimal $12 \%$, dan $0,6-1,7 \%$ untuk stevia pada penelitian Pon et al., (2015).

Subtitusi susu sapi dengan sari kedelai mungkin mempengaruhi kadar protein dan kadar lemak es krim, sedangkan variasi pemanis dapat mempengaruhi total kalori dan aktivitas antioksidan. Penggunaan sari jeruk manis diharapkan dapat menambah kadar vitamin $\mathrm{C}$ dan aktivitas antioksidan es krim. Oleh karena itu perlu diketahui pengaruh penambahan pemanis terhadap mutu fisik, kimia, dan sensori, serta formulasi pemanis terbaik yang digunakan pada es krim sari kedelai. Pada penelitian akan dilakukan pengujian sifat fisik, kimia, dan sensoris es 
krim sari kedelai jeruk manis yang ditambahkan beberapa jenis pemanis yang berbeda.

\section{METODE PENELITIAN}

\section{Bahan}

Bahan yang digunakan dalam pembuatan es krim yaitu sari kedelai yang dibuat sendiri, buah jeruk manis segar berwarna hijau kekuningan dengan semburat kuning $30-50 \%$, berdiameter $6-8 \mathrm{~cm}$, tidak terlalu matang dan tidak busuk yang diperoleh di Pasar Gede Surakarta. Bahan tambahan yang digunakan adalah sukrosa atau gula pasir "Gulaku", gelatin sapi, susu skim "Indo Prima", dan santan bubuk "Sasa" yang diperoleh dari Toko Dua Satu. Sirup fruktosa dan glukosa diperoleh dari CV Saba Kimia, serta stevia komersial "Diabetasol" (maltodekstrin, ekstrak stevia 3\%) diperoleh dari Toserba Luwes. Bahan kimia yang digunakan dalam penelitian adalah aquades, asam borat 4\%, BCG-MR, $\mathrm{H}_{2} \mathrm{SO}_{4}(93-98 \%$ bebas $\mathrm{N}), \mathrm{H}_{2} \mathrm{SO}_{4}-\mathrm{HgO}(20: 1), \mathrm{HCl}$, dietil eter, etanol $96 \%, \mathrm{NH}_{4} \mathrm{OH}$, petroleum eter (PE), amilum $1 \%$, iodium $0,01 \mathrm{~N}$, aquades, $\mathrm{Na}_{2} \mathrm{~S}_{2} \mathrm{O}_{3} 0,01 \mathrm{~N}, \mathrm{KIO}_{3} 0,01 \mathrm{~N}, \mathrm{KI} 10 \%$, $\mathrm{H}_{2} \mathrm{SO}_{4} 10 \%$, dan DPPH.

\section{Alat}

Alat yang digunakan dalam pembuatan es krim meliputi alat pemeras jeruk, baskom, freezer "Modena", ice cream machine (ICM) "ICM-105 Maksindo", kompor gas "Quantum", mixer "Philips", neraca analitik "Ohaus", refrigerator "Polytron", dan termometer $110^{\circ} \mathrm{C}$. Alat untuk analisis yaitu buret, cawan penguap, corong, desikator, destilator, hand refractometer, labu kjeldahl, labu mojonnier, neraca analitik "Ohaus", oven "Memmert", sentrifuse, spatula, spektrofotometer "Shimadzu", stopwatch, vortex, dan waterbath "Memmert".

\section{Tahapan Penelitian}

\section{Pembuatan Sari Kedelai}

Kedelai putih disortir, dicuci dan direndam. Kemudian kedelai dihaluskan dengan ditambahkan air, disaring, lalu direbus pada suhu $80^{\circ} \mathrm{C} 15$ menit (Violisa dkk., 2015).

\section{Pembuatan Sari Jeruk Manis}

Buah jeruk manis Pacitan (Citrus sinensis) dipotong menjadi dua bagian, selanjutnya buah jeruk diperas sarinya menggunakan alat pemeras, kemudian dilakukan pemisahan antara sari jeruk dan biji jeruk (Sugiarto, 2010).

\section{Pembuatan Es Krim}

Tahapan proses pembutan es krim mengacu penelitian Putri (2014). Bahanbahan yang digunakan dalam pembuatan es krim adalah sari kedelai, pemanis $(\mathrm{F} 0=$ sukrosa $12,5 \%, \mathrm{~F} 1=$ sukrosa $8,3 \%+$ fruktosa $4,16 \%, \mathrm{~F} 2=$ sukrosa $8,3 \%+$ glukosa $4,16 \%$, dan $\mathrm{F} 3=$ pemanis stevia $1 \%$ ), susu skim, santan, gelatin sapi, serta sari jeruk manis. Keseluruhan bahan kecuali sari jeruk dicampurkan dan dipasteurisasi. Sari jeruk ditambahkan saat homogenisasi menggunakan mixer ketika suhu campuran sari kedelai sudah lebih dingin. Adonan yang telah jadi dimasukkan dalam wadah tertutup dan disimpan pada suhu refrigerator $5^{\circ} \mathrm{C}$. Setelah dilakukan aging selama 20 jam, adonan dihomogenisasi menggunakan ice cream machine agar lebih mengembang. Terakhir, adonan es krim dimasukkan dalam wadah tertutup dan disimpan dalam freezer suhu $-25^{\circ} \mathrm{C}$ selama 24 jam.

\section{Parameter Pengamatan}

Parameter yang diamati adalah sifat fisik (overrun, resistensi, dan total padatan terlarut), sifat kimia (kadar protein, kadar lemak, total kalori, kadar antioksidan, dan kadar vitamin C), serta sifat sensoris es krim sari kedelai jeruk manis.

\section{Overrun (Simanungkalit, 2016)}

Volume es krim yang mengembang dinyatakan sebagai nilai overrun. Dasar perhitungannya yakni perbedaan volume es krim dengan volume adonan pada massa yang sama.

$\%=\frac{\text { berat adonan-berat es } \mathrm{krim}}{\text { berat es } \mathrm{krim}} \times 100 \%$

\section{Resistensi (Simanungkalit, 2016)}

Pengukuran resistensi dilakukan dengan cara mengambil 5 gram sampel dan ditempatkan pada sebuah piring datar. Es krim dibiarkan mencair sempurna pada suhu ruang dan diukur waktunya menggunakan stopwatch. 
Total padatan terlarut (AOAC, 2000)

Penghitungan total padatan dilakukan dengan meneteskan es krim pada prisma refraktometer kemudian mengarahkannya ke sumber cahaya untuk melihat batas gelap dan batas terang angka pengukurannya. Hasil total padatan dinyatakan dalam ${ }^{\circ}$ Brix.

\section{Kadar protein (Sudarmadji dkk., 2011)}

Metode Kjeldahl digunakan untuk menganalisis kadar protein kasar dalam bahan secara tidak langsung, yakni analisis terhadap kadar nitrogen bahan. Prinsipnya, senyawa nitrogen diubah menjadi amonium sulfat dengan $\mathrm{NaOH}$. Amoniak yang dibebaskan diikat dengan asam borat kemudian dititar dengan larutan baku asam.

$\%=\frac{(m l A-m l B) \times N H C l \times 0,014 \times 6,25 \times f p}{\text { berat sampel }}$

\section{A : $\mathrm{HCl}$ sampel}

B : $\mathrm{HCl}$ blanko

Kadar lemak Mojonnier (AOAC, 2005)

Sampel dimasukkan ke dalam tabung Mojonnier dilarutkan dengan etanol dan dihidrolisis dengan $\mathrm{NH}_{4} \mathrm{OH}$ membentuk asam lemak bebas yang kemudian diekstrak menggunakan dietil eter dan petroleum eter. Hasil ekstraksi diuapkan pelarutnya dan dikeringkan dalam oven pada suhu $100^{\circ} \mathrm{C}$ hingga bobot konstan.

$$
\% \text { lemak }=\frac{\text { berat lemak }}{\text { berat sampel }} \times 100 \%
$$

\section{Total kalori (McGill et al., 2004)}

Sebanyak 1 gram sampel ditempatkan pada tabung beroksigen yang tercelup dalam medium penyerap kalor, selanjutnya sampel terbakar oleh api listrik dari kawat logam yang terpasang dalam tabung.

\section{Kadar antioksidan (Hermayudha, 2013)}

Sebanyak 2 gram sampel diekstrak menggunakan metanol, hasil ekstraksi direaksikan dengan larutan DPPH dan diabsorbansi dengan absorban 515nm.

$$
\%=\left(1-\frac{\text { Absorbansi Sampel }}{\text { Absorbansi Blnako }}\right) \times 100 \%
$$

Kadar vitamin C (Rohim dkk., 2016)

Sebanyak 5 gram sampel dilarutkan dalam labu ukur 50ml, kemudian ditambah amilum $1 \%$ dan dititrasikan dengan larutan iod $0,01 \mathrm{~N}$ hingga berubah warna kebiruan.

$\%=\frac{m l \text { iod } \times N \text { iod } \times \text { BM vit.C } \times f p}{2 \times \text { berat sampel } \times 1000} \times 100 \%$

\section{Uji sensoris hedonik (Larnmond, 1997)}

Pada uji ini panelis mengemukakan tanggapan pribadi suka atau tidak suka, disamping itu juga mengungkapkan tingkat kesukaannya. Tingkat kesukaan disebut juga skala hedonik. Skala hedonik ditransformasikan ke dalam skala numerik dengan angka menaik menurut tingkat kesukaan. Dengan data numerik tersebut dapat dilakukan analisa statistik. Skala numerik $5=$ sangat suka, $4=$ suka, $3=$ biasa/netral, 2 = tidak suka, $1=$ sangat tidak suka.

\section{Analisis Data}

Penelitian ini menggunakan Rancangan Acak Lengkap (RAL) dengan 1 faktor perlakuan yaitu pemanis dengan dua kali pengulangan sampel dan dua kali pengulangan metode analisis. Data yang diperoleh dianalisis dengan SPSS versi 16.0 menggunakan One Way ANOVA apabila terdapat perbedaan signifikansi antar perlakuan dilanjutkan uji DMRT (Duncan Multiple Range Test) dengan taraf signifikansi sebesar 0,05 . Uji pembobotan formulasi terbaik dilakukan dengan metode De Garmo et al (1984).

\section{HASIL DAN PEMBAHASAN}

\section{Overrun}

Berdasarkan Tabel 1 nilai overrun es krim sari kedelai jeruk manis berkisar antara 26,55-41,15\% dengan hasil sampel $\mathrm{F} 3$ paling berbeda nyata terhadap sampel F0, F1, dan F2. Sampel F3 juga memiliki overrun terendah, rendahnya overrun F3 ini disebabkan oleh adanya kandungan maltodekstrin pada pemanis stevia yang digunakan. Maltodekstrin merupakan produk modifikasi pati yang berperan sebagai bahan pembawa dalam pengkristalan ekstrak steviosida berbasis air (Widagdo dkk., 2012). 
Tabel 1 Hasil Analisis Sifat Fisik Es Krim Sari Kedelai Jeruk Manis

\begin{tabular}{cccc}
\hline Sampel & Overrun (\%) & Resistensi (detik) & $\begin{array}{c}\text { Total Padatan Terlarut } \\
\left({ }^{\mathbf{0}} \text { Brix) }\right.\end{array}$ \\
\hline F0 & $37,62^{\mathrm{b}} \pm 4.97$ & $757,00^{\mathrm{a}} \pm 98,53$ & $46,50^{\mathrm{b}} \pm 1,32$ \\
F1 & $41,15^{\mathrm{b}} \pm 6,72$ & $664,33^{\mathrm{a}} \pm 129,67$ & $46,00^{\mathrm{b}} \pm 0,50$ \\
F2 & $37,92^{\mathrm{b}} \pm 5,46$ & $760,00^{\mathrm{a}} \pm 139,37$ & $45,50^{\mathrm{b}} \pm 0,86$ \\
F3 & $26,65^{\mathrm{a}} \pm 2,32$ & $1003,00^{\mathrm{b}} \pm 40,583$ & $37,17^{\mathrm{a}} \pm 1,15$ \\
\hline
\end{tabular}

Keterangan:

F0 : sukrosa $12 \%$

F1 : kombinasi sukrosa $8 \%$ dan fruktosa $4 \%$

F2 : kombinasi sukrosa $8 \%$ dan glukosa $4 \%$

$\mathrm{F} 3$ : stevia $1 \%$

Angka yang diikuti huruf yang berbeda pada kolom yang sama menunjukkan adanya beda nyata dengan taraf signifikansi $0.05 \%$.

Maltodekstrin juga digunakan untuk menghasilkan es krim rendah lemak (Singh dan Broadway, 2008). Sedangkan es krim yang rendah lemak biasanya memiliki overrun yang rendah, dikarenakan tidak banyak lemak yang berikatan dengan air yang diikat oleh gelatin. Es krim yang mengandung lemak tinggi, overrunnya akan tinggi (Hartatie, 2013). Penelitian Ozdemir et al (2015) yang membandingkan antara es krim dengan pemanis sukrosa dan ekstrak stevia bubuk, menunjukkan bahwa nilai overrun es krim stevia lebih rendah dibandingkan dengan es krim sukrosa. Selain itu adanya bahan padatan kering dalam adonan juga akan meningkatkan viskositas. Semakin kental adonan es krim, ruang partikel antar bahan juga lebih sempit dibandingkan dengan adonan encer sehingga semakin sedikit udara yang dapat terperangkap dalam adonan (Tiara dkk., 2017). Sukrosa yang digunakan dalam penelitian ini berupa gula pasir yang membutuhkan bahan cair untuk larut, oleh karena itu sampel F0 memiliki overrun yang lebih rendah dibandingkan sampel F1 dan F2. Menurut Junior dan Lannes (2011) jika dibandingkan dengan fruktosa, penambahan sirup glukosa dapat meningkatkan viskositas sehingga adonan kurang dapat mengembang saat dilakukan agitasi.

\section{Resistensi}

Resistensi pelelehan es krim sari kedelai jeruk manis berdasarkan Tabel 1 berkisar antara 664,3-1003 detik dengan hasil sampel F3 paling berbeda nyata terhadap sampel F0, F1, dan F2. Adanya maltodekstrin pada stevia yang digunakan meningkatkan viskositas adonan es krim pada saat dikenai suhu panas. Tiara dkk (2017) menyebutkan bahwa semakin tinggi viskositasnya, es krim semakin padat dan semakin lama waktu pelelehannya. Sedangkan untuk jenis pemanis lainnya, hasil penelitian Soto et al (2013) menyebutkan bahwa urutan viskositas dari yang paling besar ke kecil adalah glukosa, sukrosa, dan fruktosa. Glukosa memiliki interaksi antarmolekul yang lebih kuat dibandingkan dengan sukrosa dan fruktosa. Adanya ikatan hidrogen antar molekul glukosa menyebabkan bertambahnya polimer bercabang sehingga sirup glukosa memiiliki viskositas tinggi. Pada fruktosa terjadi peningkatan interaksi partikel dan pelarut yang menyebabkan viskositasnya rendah dan kelarutannya tinggi. Menurut Yukinori dan Osato (2012), sukrosa dapat membuat interaksi ikatan hidrogen dan interaksi hidrofobik meningkat. Juhantoro dkk (2012) menyebutkan bahwa viskositas suatu zat cair akan semakin tinggi apabila semakin banyak interaksi dan ikatan antar molekulnya.

\section{Total Padatan Terlarut}

Total padatan terlarut es krim sari kedelai jeruk manis berkisar antara 37,17$46,5^{\circ}$ Brix. Sampel F3 menunjukkan total padatan terlarut yang paling berbeda nyata terhadap sampel F1, F2, dan F0. Brix menunjukkan kadar gula atau garam terlarut dalam adonan yang dihitung setara dengan sukrosa. Selain dari pemanis tambahan, komponen gula paling dominan yang terkandung dalam sari jeruk manis adalah sukrosa. Menurut Atviolani (2016), peningkatan total padatan terlarut disebabkan 
karena pengikatan air bebas oleh sukrosa sehingga konsentrasi bahan yang larut meningkat. Rendahnya respon Brix pada sampel F3 disebabkan karena konsentrasi stevia sampel F3 yang dipakai hanya $1 \%$ dan tidak dikombinasikan dengan sukrosa. Total padatan memiliki peranan terhadap tekstur dan kenampakan es krim. Es krim dengan total padatan yang tinggi memiliki tekstur dan kenampakan yang lebih baik dibandingkan dengan es krim yang total padatannya rendah. Tingginya total padatan berpengaruh terhadap rendahnya kadar air dalam adonan. Hanya sedikit air yang terbentuk menjadi kristal es sehingga menghasilkan es krim dengan tekstur yang lembut (Syed et al., 2018). Total padatan es krim sari kedelai jeruk manis telah memenuhi persyaratan total padatan es krim SNI (1995) yakni minimal 3,4.

Tabel 2 Hasil Analisis Sifat Kimia Es Krim Sari Kedelai Jeruk Manis

\begin{tabular}{cccccc}
\hline Sampel & $\begin{array}{c}\text { Kadar } \\
\text { Protein } \\
(\boldsymbol{\%})\end{array}$ & $\begin{array}{c}\text { Kadar } \\
\text { Lemak (\%) }\end{array}$ & $\begin{array}{c}\text { Total Kalori } \\
(\mathbf{k a l} / \text { gram })\end{array}$ & $\begin{array}{c}\text { Aktivitas } \\
\text { Antioksidan } \\
(\boldsymbol{\%})\end{array}$ & $\begin{array}{c}\text { Kadar } \\
\text { Vitamin } \mathbf{C} \\
(\boldsymbol{\%})\end{array}$ \\
\hline F0 & $4,87^{\mathrm{a}} \pm 0,07$ & $0,03^{\mathrm{ab}} \pm 0,015$ & $1938,58^{\mathrm{c}} \pm 12,28$ & $60,83^{\mathrm{b}} \pm 0,01$ & $0,24^{\mathrm{b}} \pm 0,02$ \\
F1 & $5,21^{\mathrm{b}} \pm 0,16$ & $0,03^{\mathrm{a}} \pm 0,008$ & $1929,37^{\mathrm{c}} \pm 7,11$ & $63,88^{\mathrm{c}} \pm 0,01$ & $0,24^{\mathrm{b}} \pm 0,02$ \\
F2 & $4,95^{\mathrm{a}} \pm 0,05$ & $0,06^{\mathrm{b}} \pm 0,010$ & $1891,82^{\mathrm{b}} \pm 8,49$ & $64,88^{\mathrm{d}} \pm 0,05$ & $0,26^{\mathrm{b}} \pm 0,01$ \\
F3 & $5,77^{\mathrm{c}} \pm 0,11$ & $0,03^{\mathrm{a}} \pm 0,001$ & $1621,79^{\mathrm{a}} \pm 12,63$ & $56,90^{\mathrm{a}} \pm 0,03$ & $0,20^{\mathrm{a}} \pm 0,01$ \\
\hline
\end{tabular}

Keterangan:

F0 : sukrosa $12 \%$

F1 : kombinasi sukrosa $8 \%$ dan fruktosa $4 \%$

F2 : kombinasi sukrosa $8 \%$ dan glukosa $4 \%$

F3 : stevia $1 \%$

Angka yang diikuti huruf yang berbeda pada kolom yang sama menunjukkan adanya beda nyata dengan taraf signifikansi $0.05 \%$.

\section{Kadar Protein}

Berdasarkan Tabel 2, kadar protein es krim sari kedelai jeruk manis berkisar antara 4,87-5,77\%. Sampel F1 dan F3 menunjukkan paling beda nyata. Sampel F3 mengandung kadar protein tertinggi dibandingkan dengan sampel lainnya. Menurut Gupta et al (2013), stevia merupakan tanaman yang kaya akan nutrisi seperti mineral, protein, serat, asam amino, bebas gula, dan nutrisi lainnya. Beberapa penelitian menyebutkan bahwa kandungan protein dalam daun stevia cukup tinggi yakni berkisar antara 10-16 gram/100 gram berat kering. Penelitian Widodo dkk (2015) menunjukkan bahwa produk yang menggunakan ekstrak daun stevia memiliki kandungan protein lebih tinggi dibandingkan dengan sukrosa. Semakin meningkat konsentrasi ekstrak daun stevia, protein semakin tinggi. Rendahnya kadar protein sampel F0 didukung oleh penelitian Raatz et al (2015) yang menyebutkan bahwa kandungan protein dalam 100 gram gula adalah 0 gram. Kadar protein pada es krim sari kedelai jeruk manis tidak hanya dipengaruhi oleh jenis pemanis yang digunakan, namun juga dipengaruhi oleh sari kedelai, santan, susu skim, dan bahan-bahan lainnya. Kadar protein per 100 gram sari kedelai sebesar 3,3 - 3,5\% (Sari dkk., 2017) sedangkan pada susu skim sebesar $15 \%$. Secara keseluruhan, kadar protein es krim sari kedelai sari buah jeruk telah memenuhi persyaratan SNI mutu es krim tahun 1995 yakni minimal $2.7 \%$.

\section{Kadar Lemak}

Kadar lemak es krim sari kedelai jeruk manis berdasarkan Tabel 2 berkisar antara 0,025-0,055\%. Sampel F2 berbeda nyata terhadap sampel F1 dan F3 namun tidak berbeda nyata terhadap sampel F0. Ekstrak daun stevia mengandung lemak sebesar 2,23\% (Widodo dkk., 2015). Penggunaan stevia sebagai pengganti sukrosa dapat mempengaruhi tekstur es krim karena dapat berpengaruh terhadap kestabilan lemak dalam es krim (Pon et al., 2015). Hasil penelitian Ozdemir et al (2015) menunjukkan bahwa kadar lemak es krim dengan gula sukrosa lebih tinggi dibandingkan kadar lemak es krim dengan stevia. Meskipun selisihnya tidak terpaut jauh. Menurut Junior dan Lannes (2011) kadar lemak es krim 
kombinasi sukrosa-glukosa lebih tinggi dibandingkan es krim kombinasi sukrosafruktosa. Es krim yang memakai sirup glukosa menghasilkan lemak terdestabilisasi yang tinggi pada saat pengocokan dengan mixer. Tinggi rendahnya lemak akan mempengaruhi tekstur es krim. Semakin sedikit kandungan lemaknya, akan terbentuk kristal es yang kasar selama penyimpanan (Muse dan Hartel, 2004). Es krim sari kedelai jeruk manis memiliki kadar lemak yang rendah di bawah batas SNI es krim (1995) yakni minimal 5\%. Rendahnya kadar lemak ini disebabkan oleh subtitusi susu sapi dengan sari kedelai, penggunaan lemak nabati dibandingkan dengan lemak hewani, dan bahan-bahan rendah lemak lainnya.

\section{Total Kalori}

Hasil penghitungan total kalori es krim sari buah jeruk berdasarkan Tabel 2 berkisar antara 1621,79-1938,58 kal/gram. Total kalori sampel F2 dan F3 menunjukkan paling beda nyata. Penelitian Junior dan Lannes (2011) menyebutkan kalori dalam es krim dengan kombinasi pemanis sukrosa-glukosa lebih rendah dibandingkan kombinasi pemanis sukrosa-fruktosa. Adanya perbedaan bentuk karbohidrat memungkinkan terjadinya hal tersebut. Substitusi pemanis dengan stevia $1 \%$ menghasilkan es krim dengan total kalori yang rendah. Stevia memang merupakan pemanis rendah kalori. Hal ini telah sesuai dengan Alizadeh et al (2014) yang menyebutkan bahwa total kalori es krim dengan pemanis stevia menurun dibandingkan dengan es krim sukrosa. Widodo dkk (2015) juga menyebutkan hal yang sama, stevia dapat menggantikan gula sukrosa dan menurunkan nilai kalori secara signifikan. Total kalori es krim sari kedelai jeruk manis per 100 gram masing-masing adalah F0 193,8 kkal, F1 192,9 kkal, F2 189,2 kkal, dan F3 162,2 kkal. Total kalori tersebut lebih rendah dibandingkan dengan es krim komersial yang berkisar antara 250 $300 \mathrm{kkal} / 100$ gram.

\section{Aktivitas Antioksidan}

Berdasarkan Tabel 2, hasil pengujian aktivitas antioksidan menunjukkan adanya perbedaan nyata antar sampel. Kadar antioksidan es krim berkisar antara 56,9025$64,8825 \%$. Jenis pemanis berpengaruh terhadap aktivitas antioksidan. Pengurangan konsentrasi sukrosa dalam es krim justru meningkatkan aktivitas antioksidannya. Hal ini sesuai dengan Andriani dkk (2012) yang menyebutkan bahwa semakin tinggi konsentrasi gula yang ditambahkan, senyawa polifenol semakin banyak mengikat molekul gula. Sehingga pelarutan komponen polifenol terganggu. Total fenol mengalami penurunan paling besar dengan penambahan gula pasir. Sampel F3 menghasilkan aktivitas antioksidan paling rendah pada es krim sari kedelai jeruk manis. Pemanis stevia mengandung senyawa polifenol, aktivitas antioksidannya berkisar antara 1,99-4,73\% (Beben et al., 2015). Namun karena pada pembuatan es krim sari kedelai jeruk manis ini konsentrasi yang ditambahkan hanya $1 \%$, sehingga aktivitas antioksidannya juga rendah.

\section{Kadar Vitamin C}

Hasil penghitungan kadar vitamin $\mathrm{C}$ es krim berdasarkan Tabel 2 berkisar antara 0,20416-0,26224\% Sampel F3 paling berbeda nyata terhadap sampel F0, F1, dan F2. Selisih kadar vitamin C antar sampel tidak jauh. Penambahan sukrosa dengan konsentrasi tertentu dapat menyebabkan produk lebih pekat dan menjadi larutan hipertonik sehingga kandungan vitamin $\mathrm{C}$ dalam produk dapat terlindungi (Laili dkk., 2017 dalam Devianti dan Ratih, 2018). Akan tetapi, penambahan sukrosa yang berlebihan dapat menurunkan kadar vitamin $\mathrm{C}$ (Octaviani dan Rahayuni, 2014). Penambahan sukrosa yang tinggi menyebabkan lebih banyak air yang keluar pada bahan sehingga air akan melarutkan vitamin $C$ yang bersifat larut dalam air (Joseph dkk., 2017). Menurut Devianti dan Ratih (2018) pada penelitiannya terhadap sari buah, penurunan kadar vitamin $\mathrm{C}$ terjadi lebih lambat pada sampel dengan penambahan sukrosa dibandingkan sampel tanpa penambahan sukrosa. Pada penelitian, sampel F0, F1, dan F2 yang ditambahkan sukrosa memiliki kadar vitamin C lebih tinggi dibandingkan sampel F3 yang hanya menggunakan stevia. 
Tabel 3 Hasil Analisis Sifat Sensoris Es Krim Sari Kedelai Jeruk Manis

\begin{tabular}{cccccc}
\hline Sampel & Warna & Aroma & Tekstur & Rasa & Overall \\
\hline F0 & $3,87^{\mathrm{a}} \pm 0,86$ & $3,50^{\mathrm{ab}} \pm 0,68$ & $3,37^{\mathrm{a}} \pm 0,61$ & $3,53^{\mathrm{a}} \pm 0,86$ & $3,40^{\mathrm{ab}} \pm 0,89$ \\
F1 & $3,97^{\mathrm{a}} \pm 0,71$ & $3,73^{\mathrm{b}} \pm 0,74$ & $3,80^{\mathrm{b}} \pm 0,71$ & $3,67^{\mathrm{a}} \pm 0,92$ & $3,83^{\mathrm{b}} \pm 0,87$ \\
F2 & $3,80^{\mathrm{a}} \pm 0,66$ & $3,53^{\mathrm{ab}} \pm 0,90$ & $3,73^{\mathrm{b}} \pm 0,58$ & $3,70^{\mathrm{a}} \pm 0,83$ & $3,60^{\mathrm{ab}} \pm 0,67$ \\
F3 & $3,87^{\mathrm{a}} \pm 0,81$ & $3,30^{\mathrm{a}} \pm 0,70$ & $3,57^{\mathrm{ab}} \pm 0,77$ & $3,53^{\mathrm{a}} \pm 1,13$ & $3,33^{\mathrm{a}} \pm 0,84$ \\
\hline
\end{tabular}

Keterangan:

F0 : sukrosa $12 \%$

F1 : kombinasi sukrosa $8 \%$ dan fruktosa $4 \%$

F2 : kombinasi sukrosa $8 \%$ dan glukosa $4 \%$

F3 : stevia $1 \%$

Angka yang diikuti huruf yang berbeda pada kolom yang sama menunjukkan adanya beda nyata dengan taraf signifikansi $0.05 \%$. Skor tingkat kesukaan $1=$ sangat tidak suka; $2=$ tidak suka; $3=$ netral; $4=$ suka; $5=$ sangat suka.

\section{Warna}

Berdasarkan Tabel 3, parameter warna antar sampel tidak berbeda nyata. Skor penilaian parameter warna berkisar antara 3,8-3,97. Jenis pemanis tidak berpengaruh terhadap penilaian parameter warna es krim. Pemanis yang digunakan berwarna bening saat dilarutkan. Pada pembuatan es krim, yang memberikan pengaruh terhadap warna adalah sari buah jeruk. Penambahan sari buah jeruk memberikan warna kuning cerah. Namun menurut Meilgaard dkk., (1999) dalam Jumri, dkk., (2015), faktor-faktor seperti cahaya lampu, dekorasi ruangan, serta ukuran dan bentuk produk dapat mempengaruhi penilaian panelis terhadap parameter warna.

\section{Aroma}

Berdasarkan Tabel 3, parameter aroma antar sampel terlihat adanya beda nyata. Skor penilaian parameter aroma berkisar antara 3,3-3,73. Aroma es krim sangat dipengaruhi oleh bahan-bahan yang digunakan dalam pembuatan es krim. Bahan-bahan perlu dipastikan terlebih dahulu kualitasnya agar tidak terdapat penyimpangan aroma seperti tengik, metalik, ataupun langu (Hartatie, 2011). Hasil uji one way ANOVA dan DMRT menunjukkan bahwa jenis pemanis yang digunakan tidak berpengaruh terhadap penilaian aroma es krim sari kedelai jeruk manis, karena pemanis sukrosa yang digunakan tidak memiliki aroma. Pada pembuatan es krim, yang memberikan pengaruh terhadap aroma adalah sari kedelai, santan, susu skim, dan sari buah jeruk. Penambahan sari buah jeruk dapat menutupi aroma langu kedelai.

\section{Tekstur}

Berdasarkan Tabel 3, parameter tekstur antar sampel terlihat adanya beda nyata. Skor penilaian parameter tekstur berkisar antara 3,37-3,8. Bahan yang paling berperan penting dalam pembentukan tekstur ialah lemak. Lemak berkontribusi dalam menghasilkan tekstur yang halus, menambah cita rasa serta flavor es krim, dan memperindah kenampakan. Kandungan lemak yang rendah pada bahan es krim akan menghasilkan es krim dengan kristal es yang besar dan kasar. Hal ini akan mengurangi skor penilaian konsumen terhadap tekstur. Konsumen menyukai tekstur yang halus dan lembut. Selain formulasi bahan, daya kembang es krim dan kondisi penyimpanan juga berpengaruh terhadap tekstur es krim yang dihasilkan (Hartatie, 2011). Hasil analisis overrun es krim sari kedelai jeruk manis juga menunjukkan bahwa sampel F1 memiliki overrun yang tinggi, sehingga skor penilaian parameter teksturnya juga tinggi.

\section{Rasa}

Berdasarkan Tabel 3, parameter rasa antar sampel tidak berbeda nyata. Skor penilaian parameter rasa berkisar antara 3,53-3,7. Rasa yang diinginkan oleh panelis pada produk es krim adalah tidak terlalu manis dan tidak pahit, asam atau rasa lain yang mengganggu (Violisa dkk., 2012). Jenis pemanis tidak berpengaruh nyata terhadap rasa es krim. Es krim sari kedelai ditambahkan sari jeruk untuk menutupi rasa langunya. Hal ini sesuai dengan pernyataan Wahyuni (2016), penambahan buah-buahan juga dapat berfungsi sebagai pemberi rasa. Kandungan protein dan lemak juga bisa menjadi faktor yang mempengaruhi rasa es 
krim (Pangga dkk., 2014). Sampel F2 memiliki kadar lemak tertinggi dan kadar protein yang cukup tinggi di antara sampel es krim lainnya.

\section{Overall}

Berdasarkan Tabel 3, parameter overall antar sampel terlihat adanya beda nyata. Skor penilaian parameter overall berkisar antara 3,33-3,83. Hasil uji one way ANOVA dan DMRT menunjukkan bahwa jenis pemanis tidak berpengaruh nyata terhadap overall es krim. Keseluruhan produk es krim sari kedelai jeruk manis dapat diterima oleh panelis dan yang paling diterima oleh panelis adalah F1. Sampel F3 meskipun memiliki skor paling rendah tetapi pemanis stevia juga memiliki potensi yang besar sebagai pengganti sukrosa dalam pembuatan es krim.

\section{Formulasi Terbaik}

Pemilihan formulasi terbaik pada pembuatan es krim sari kedelai jeruk manis dilakukan dengan uji indeks efektivitas atau uji pembobotan berdasarkan masing-masing parameter fisik, kimia, dan sensoris. Metode yang digunakan adalah indeks efektivitas yang mengacu pada De Garmo et al (1984). Skor hasil uji pembobotan F0, F1, F2, dan F3 yakni 0,$39 ; 0,75 ; 0,54$; dan 0,38 . F1 dengan formulasi kombinasi sukrosa $8,3 \%$ dan fruktosa $4,16 \%$ memiliki nilai pembobotan tertinggi sehingga F1 dipilih sebagai formulasi terbaik es krim sari kedelai jeruk manis.

\section{KESIMPULAN}

Hasil pengujian es krim sari kedelai jeruk manis, pemanis sukrosa, fruktosa, glukosa, dan stevia berpengaruh terhadap mutu fisik (overrun, resistensi, dan total padatan terlarut) dan kimia (kadar protein, total kalori, kadar lemak, aktivitas antioksidan, dan kadar vitamin C) es krim. Namun tidak berpengaruh nyata terhadap sifat sensoris es krim dengan skor tertinggi parameter overall adalah F1 sebesar 3.83 (netral ke arah suka). Formulasi terbaik pada es krim sari kedelai dengan penambahan sari buah jeruk adalah F1 (kombinasi sukrosa $8,3 \%$ + fruktosa $4,16 \%)$.
Penelitian ini dapat dikembangkan lebih lanjut agar dapat diketahui cara pengemasan yang tepat dan umur simpannya. Selain itu dapat dilakukan pula penelitian terkait kombinasi buah jeruk dan buah lainnya untuk meningkatkan sifat fungsional es krim.

\section{DAFTAR PUSTAKA}

Alizadeh, M., Maryam, AL. \& Sorayya, K. (2014). Impact of Using Stevia on Physicochemical, Sensory, Rheology and Glycemic Index of Soft Ice Cream. Journal of Food and Nutrition Sciences, 5(4): 391-392.

Andani, SA. \& Nurmasari, W. (2017). Pengaruh Pemberian Jus Jeruk Manis (Citrus sinensis.) terhadap Nilai $\mathrm{Vo}_{2} \max$ Atlet Sepak Bola di Gendut Dony Training Camp (GDTC) Salatiga. Jurnal Gizi Indonesia, 5(2): 68-69.

Andreasen, TG. \& Nielsen. (1998). Ice Crream and Aerated Dessert. The Technology of Dairy Products Blackie Academic and Profesional. London Weinheim, New York

Andriani, M., Bambang, SA. \& Gandes. (2012). Pengaruh Penambahan Gula Dan Suhu Penyajian Terhadap Nilai Gisi Minuman Teh Hijau (Camellia sinensis L.). Jurnal Teknologi Hasil Pertanian, 5(2): 40-47.

Association of Official Analytical Chemistry (AOAC). (2000). Official Methods of Analysis. Mc Graw Hill Press, Canada.

Association of Official Analytical Chemistry (AOAC). (2005). Official Methods of Analysis. Mc Graw Hill Press, Canada.

Atviolani, R. (2016). Pengaruh Konsentrasi Sukrosa dan Pektin terhadap Karakteristik Marmalade Buah Naga Merah (Hylocereus polyrhizus). Skripsi.

Universitas Pasundan Bandung.

Badan Standardisasi Nasional (BSN). (1995). SNI 01-3713-1995 Es krim. Jakarta.

Beben, KG., Tomasz, B., Zofia, NL., Beata, A., Anna, J., Monika, K. \& Kamila, R. (2015). Stevia Rebaudiana Bert. Leaf Extracts as a Multifunctional Source of Natural Antioxidants. Journal of Molecules, 20(10): 5468-5481. 
Clarke, C. (2004). The Science of Ice Cream. Royal Society of Chemistry, Cambridge.

Darma, GS., Diana, P. \& Endang, N. (2013). Pembuatan Es Krim Jagung Manis Kajian Jenis Zat Penstabil, Konsentrasi Non Dairy Cream serta Aspek Kelayakan Financial. Jurnal Reka Industri, 1(1): 45-46.

De Garmo, EPWGS. \& Canada, JR. (1984). Engineering Economy The 7th Edition. MacMillan Publishing Comp, New York. Devianti, VA. \& Ratih, KW. (2018). Degradasi Vitamin C dalam Jus Buah dengan Penambahan Sukrosa dan Lama Waktu Konsumsi. Journal of Research and Technology, 4(1): 41-46.

Failisnur. (2013). Karakteristik Es Krim Bengkuang dengan Menggunakan Beberapa Jenis Susu. Jurnal Litbang Industri, 3(1): 11-12.

Goff, HD. \& Hartel, RW. (2004). Ice cream and frozen desserts. Guelph University E-Book, Canada.

Gupta, E., Shalini, P., Shanty, S. \& GK., Rai. (2013). Nutritional and therapeutic values of Stevia rebaudiana: A review. Journal of Medical Plants, 7(46): 33433353.

Hajirostamloo, B. (2009). Comparison of Nutritional and Chemical Parameters of Soymilk and Cow Milk. International Journal of Nutrition and Food Engineering, 3(9): 455-456.

Hartatie, ES. (2011). Kajian Formulasi (Bahan Baku , Bahan Pemantap) dan Metode Pembuatan Terhadap Kualitas Es Krim. E-journal Gamma, 7(1): 20-26.

Hermayudha, E., Munifatul, I. \& Endang, S. (2013). Uji Total Glukosa dan Aktivitas Antioksidan Beberapa Produk Pangan Fungsional Berbahan Dasar Ubi Jalar Ungu (Ipomoea batatas 1.) var Ayamurasaki. Jurnal Biologi, 2(2): 3435.

Junior, EDS. \& Suzana, CDSL. (2011). Effect of Different Sweetener Blends and Fat Types on Ice Cream Properties. Journal of Food Properties, 31(1): 217220.

Joseph, GS., Lana, L. \& Maria, FS. (2017). Pengaruh Sukrosa terhadap Karakteristik Fisikokimia dan Sensoris
Manisan Kering Paprika Merah (Capsicum Annuum Var Grossum). Naskah Publikasi. Universitas Sam Ratulangi Manado.

Juhantoro, N., Ariana, IM. \& Semin, S. (2012). Penentuan Properties Bahan Bakar Batubara Cair untuk Bahan Bakar Marine Diesel Engine. Jurnal Teknik, 1(1): 271-274.

Laili, M., Alimuddin. \& Erwin. (2017). Penetapan Kadar Vitamin C dalam Sirup Buah Naga Merah (Hylocereus polyrhizus) dengan Variasi Waktu Penyimpanan. Jurnal Atomik, 2(1): 128133.

Larnmond, E. (1997). Laboratory Method for Sensory Evaluation. Department of Agriculture Publication, Ottawa.

Meilgaard, M., Civille, GV. \& Carr, BT. (1999). Sensory Evaluation Techniques. CRC Press, New York.

McGill, KC., Michelle, LY. \& Wendy, KN. (2004). Determination of Calories in Food via Adiabatic Bomb Calorimeter. Journal of Student Research, 6(9): 93-96. Muse, MR. \& Hartel, RW. (2004). Ice Cream Structural Elements that Affect Melting Rate and Hardness. Journal of Dairy Science, 87(1): 1-10.

Octaviani, LF. \& Arintina, R. (2014). Pengaruh Berbagai Konsentrasi Gula terhadap Aktivitas Antioksidan dan Tingkat Penerimaan Sari Buah Buni (Antidesma Bunius). Journal of Nutrition College, 3(4): 958-965.

Ozdemir, C., Arslaner, A., Ozdemir, S. \& Allahyari, M. (2015). The Production of Ice Cream Using Stevia as a Sweetener. Journal of Food Sci Technol, 10(1007): 1784-1787.

Pangga, NR. (2014). Penggunaan Whippy Cream dalam Pembuatan Es Krim Soyghurt Used of Whippy Cream To Making Ice Cream Soyghurt. Naskah Publikasi. Universitas Riau.

Pon, SY., Lee, WJ. \& Chong, GH. (2015). Textural and Rheological Properties of Stevia Ice Cream. International Food Research Journal, 22(4): 1544-1549.

Putri, MA. (2014). Pengaruh Ekstrak Rosella terhadap Kualitas Es Krim Susu Kedelai. Skripsi. Universitas Negeri Padang. 
Raatz, SK., Luann, KJ. \& Matthew, JP. (2015). Consumption of Honey, Sucrose, and High-Fructose Corn Syrup Produces Similar Metabolic Effects in GlucoseTolerant and Intolerant Individuals. Journal of Nutrition, 2(10): 2265-2272.

Rohim, A., Alimuddin \& Erwin (2016). Analisis Kandungan Asam Askorbat dalam Buah Naga Merah (Hylocereuspolyrhizus) dengan Iodimetri. Jurnal Kimia, 14(1): 42-43.

Sari, PC., Al-Baari, Ahmad, N., Legowo \& Anang, M. (2017). Karakteristik Fisikokimiawi Whey Keju Kedelai dengan Menggunakan Sari Belimbing Wuluh (Averrhoa bilimbi) sebagai Koagulan. Skripsi. Universitas Diponegoro.

Sari, RP. \& Amelia, ED. (2018). Pemberian Air Perasan Jeruk Manis (Citrus sinensis) Meningkatkan Kadar LDL Kolesterol Serum. Artikel Penelitian, 1(2): 93-94.

Simanungkalit, H., Indriyani \& Ulyarti. (2016). Kajian Pembuatan Es Krim dengan Penambahan Kacang Merah (Phaseolus Vulgaris L.). Jurnal Teknologi Pertanian, 18(1): 20-26.

Singh, A. \& AA., Broadway. (2008). A Study on Manufacture of Low Fat Ice Cream. Allahabad Farmer Journal, 64(1): 12-16. Sugiarto, EP. (2010). Penambahan Asam Sitrat yang Berbeda Pada Proses Pembuatan Sirup Jeruk Nipis terhadap Kualitas Sirup yang Dihasilkan. Skripsi. Politeknik Pertanian Negeri Samarinda.

Sumarjiana, I. (2011). Lactose Intolerance: Suatu Kasus Ketidakmampuan Usus untuk Mencerna Lactose. Widyatech Jurnal Sains dan Teknologi, 10(3): 1-13.

Sumarno \& Harnoto. (1983). Kedelai dan Cara Bercocok Tanamnya. Pusat Penelitian dan Pengembangan Tanaman Pangan, Bogor.

Syed, QA., Saba, A., Riwan, S. \& Tahir, Z. (2018). Effects of Different Ingredients on Texture of Ice Cream. Journal of Nutritional Health \& Food Engineering, 8(6): 422-435.

Terhaag, MM., Mariana, BA. \& Marta, dTB. (2013). Soymilk Plain Beverages: Correlation Between Acceptability and
Physical and Chemical Characteristics. Journal of Food Science and Technology, 33(2): 387.

Tiara, C., Merkuria, K. \& Nanik, S. (2017). Karakteristik Fisikokimia dan Sensori Es Krim Temulawak (Curcuma Xanthorriza) dengan Variasi Penambahan Bubur Buah Nanas (Ananas comosus). Jurnal Teknologi dan Industri Pangan, 7(2): 35-36.

Violisa, A., Amat, N. \& Nunung, N. (2012). Penggunaan Rumput Laut Sebagai Stabilizer Es Krim Susu Sari Kedelai. Jurnal Teknologi dan Kejuruan, 35(1): 103-105.

Wahyuni, A. (2016). Kualitas Dadih Kedelai dengan Penambahan Sari Jeruk Manis dan Jambu Biji. Skripsi. Universitas Muhammadiyah Surakarta.

Wariyah, C. (2010). Vitamin C Retention and Acceptability of Orange (Citrus nobilis var. Microcarpa) Juice during Storage in Refrigerator. Jurnal AgriSains, 1(1): 5052.

Widagdo, OCJ., November, RA., Fandi, AD. \& Yohanes M. (2012). Kristalisasi Steviosiada Berbasis Air dan PraFormulasinya dari Stevia rebaudiana (Bert). sebagai Pemanis Alami Rendah Kalori. Prosiding Seminar Nasional Sains dan Pendidikan Sains VII UKSW 2012.

Widodo., Naimatun, N. \& Indratiningsih. (2015). Produksi Low Calorie Sweet Bio-Yoghurt dengan Penambahan Ekstrak Daun Stevia (Stevia Rebaudiana) sebagai Pengganti Gula. Jurnal Agritech, 35(4): 464-471.

Yukinori, S. \& Osato, M. (2012). Analysis of Apparent Viscosity of Aqueous Macromolecule Solutions Containing Sucrose. Food Sci Technol Research, 18(4): 563-570. 